\title{
Prevalence of alterations in chest computerized tomography in patients with head and neck cancer
}

\section{Prevalência das alterações em tomografias computadorizadas de tórax em pacientes com câncer de cabeça e pescoço}

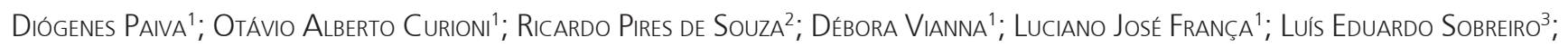
Rogério Aparecido Dedivitis, TCBC-SP4; Abrão Rapoport, ECBC-SP5

\section{A}

\begin{abstract}
Objective: to assess the prevalence of abnormalities found by computed tomography (CT) of the chest in patients with squamous cell carcinoma of the head and neck. Methods: we retrospectively analyzed chest CT exams of 209 patients with squamous cell carcinoma of the head and neck. The CT findings were stratified as inflammatory / infectious, parenchymal, nodular uncharacteristic and nodular metastatic/tumoral Results: alterations were diagnosed in $66.6 \%$ of patients. Of these, $25.3 \%$ represented emphysema; $18.8 \%$, uncharacteristic micronodules; $12.9 \%$, metastases; $11.9 \%$, thoracic lymph node enlargements; and in $6.6 \%$ we detected active pulmonary tuberculosis or its sequelae, pneumonia or inflammatory / infectious signs and pleural thickening or effusion. Conclusion: the prevalence of exams with alterations and the considerable rate of detected metastases indicate that chest CT should be required for diagnostic and / or staging in cases of head and neck cancer.
\end{abstract}

Key words: Carcinoma, Squamous Cell. Head and Neck Neoplasms. Tomography, X-Ray Computed. Neoplasm Staging. Mass Screening.

\section{INTRODUCTION}

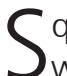
quamous cell carcinoma of the head and neck is a worldwide public health problem and, despite advances in therapeutic and diagnostic methods, patients displayed no increase in overall survival in recent decades. This has been attributed, among other factors, to the emergence of distant metastases and the development of second primary tumors. The presence of these manifestations may affect prognosis and management ${ }^{1-3}$.

The information arising from imaging analysis is an important component for the initial staging and posttreatment evaluation of patients with squamous cell carcinoma of the head and neck ${ }^{4}$. Additionally, the American Joint Committee on Cancer (AJCC) staging Manual states that any diagnostic information that contributes to the overall accuracy of pretreatment assessment should be considered in planning the treatment of such patients ${ }^{5}$.

A chest X-ray was used for several years to complement head and neck cancer diagnosis / staging. However, over time it showed not to be effective in providing early diagnosis of such alterations ${ }^{6}$. Pan-endoscopy was also used as an alternative method of screening, with reports of
$2-16 \%$ of second primary tumor detection, but in the lung it tends not to have a good effectiveness in detecting metastases due to the peripheral distribution of such lesions lesions ${ }^{2}$.

It is noteworthy that computed tomography (CT) has a good accuracy in differentiating lesions with metastatic pattern from the ones without oncologic meaning, causing head and neck surgeons to resort to radiologists for the aid in planning the best treatment ${ }^{7}$. Even in non-neoplastic findings, alterations can be found which, although not increasing mortality, increase morbidity, such as emphysema.

The aim of this study was to evaluate the prevalence of alterations found in chest CT exams of patients with squamous cell carcinoma of the head and neck.

\section{METHODS}

This study was approved by the Ethics in Research Committee of the Hospital Heliopolis, under the number 400/2005.

1. Departamento de Cirurgia de Cabeça e Pescoço - Otorrinolaringologia, Hospital Heliópolis, São Paulo; 2. Serviço de Radiologia Hospital Heliópolis, São Paulo; 3. Serviço de Radiologia do Hospital Heliópolis, São Paulo; 4. Grupo de Laringe do Departamento de Cirurgia de Cabeça e Pescoço do Hospital das Clínicas da Faculdade de Medicina da Universidade de São Paulo; 5. Hospital Heliópolis, São Paulo. 
We retrospectively analyzed chest CT scans of 209 patients with squamous cell carcinoma of the head and neck, between August 2010 and April 2011, in order to determine and quantify the most prevalent alterations in these exams. Should the reports present diagnostic uncertainty, there was revaluation of the images with the radiology team for clarification and final decision by consensus on the alterations found. For this study, CT findings were stratified as: inflammatory / infectious, parenchymal, nodular uncharacteristic and nodular metastatic / tumoral. The uncharacteristic nodules included the ones smaller than $7 \mathrm{~mm}$, with no classic features of metastasis.

\section{RESULTS}

Alterations consistent with chronic obstructive pulmonary disease were the most frequent, followed by uncharacteristic micronodules(Figure 1), representing 25.3\% and $18.8 \%$, respectively. It should be noted that, in some cases, more than one alterations occurred in the same exam (Table 1). Lung metastases amounted to $12.9 \%$ (Figure 2).

\section{DISCUSSION}

The presence of synchronous lung tumors or thoracic metastases in patients with head and neck cancer have prognostic implications and may have major impact on treatment ${ }^{4,8}$. In addition, second primary tumors account for approximately half of deaths in patients with successfully eradicated primary head and neck cancer ${ }^{9}$. Such second primaries are often located in the chest, showing the importance of screening in this region and the use of CT for this purpose. The most common site of distant metastasis are the lungs and various centers around the world consider screening for lung metastasis important in these patients ${ }^{7}$. However, the widespread use of CT is still controversial, since, theoretically, it would have a

Table 1 - Prevalence of alterations in chest CT scans of patients with squamous cell carcinoma of the head and neck.

\begin{tabular}{lcr}
\hline Tomographic Findings & Number of cases & \% \\
\hline COPD / emphysema & 53 & 25.3 \\
Uncharacteristic micronodules & 38 & 18.8 \\
Metastases & 27 & 12.9 \\
Intrathoracic lymph nodes & 25 & 11.9 \\
Tuberculosis (active or sequelae) & 14 & 6.6 \\
Inflammatory / infectious signs & 14 & 6.6 \\
Pleural effusion / thickening & 14 & 6.6 \\
Total tests with alterations & 136 & 66.6 \\
\hline
\end{tabular}

greater impact on therapy by detecting alterations in initial cases, although some authors demonstrate limitations of its routine use in all cases, especially in the newly diagnosed ${ }^{10}$. Thus, there was search for parameters associated with a positive chest CT scan, such as the occurrence of regional metastases in stages N2 / N3 and the primary tumor having origin in the oropharynx, hypopharynx or supraglottic region ${ }^{11}$.

The effectiveness of chest $\mathrm{CT}$ compared with conventional radiography in screening for metastases or concomitant primary tumors is not an issue, since CT can detect smaller lesions and certainly allows for better visibility of the lungs than plain radiography, although costeffectiveness has been called into question in early ca-

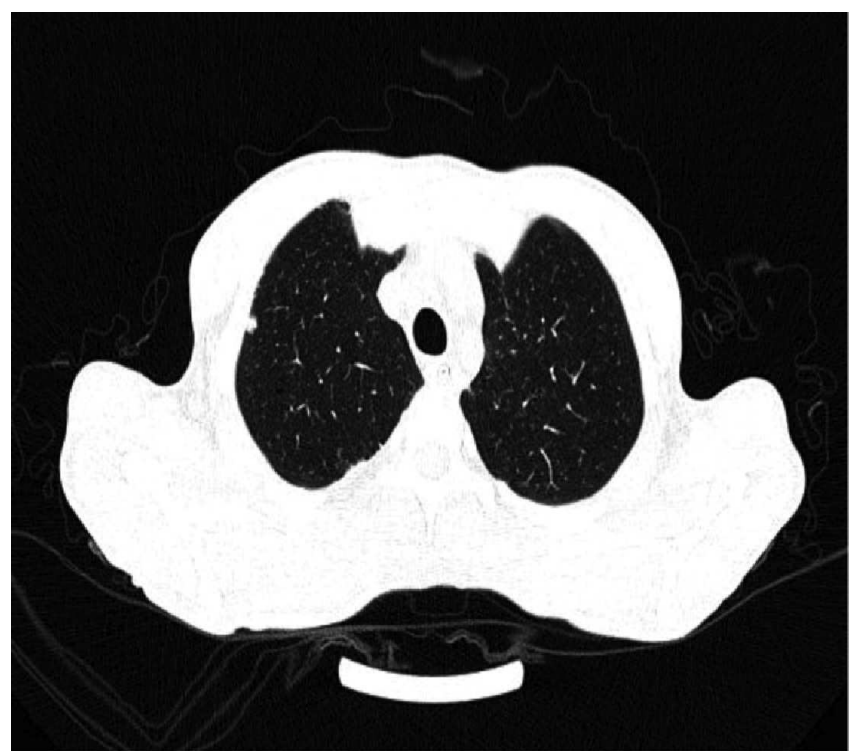

Figure 1 - Computed tomography of the chest showing right uncharacteristic micronodule.

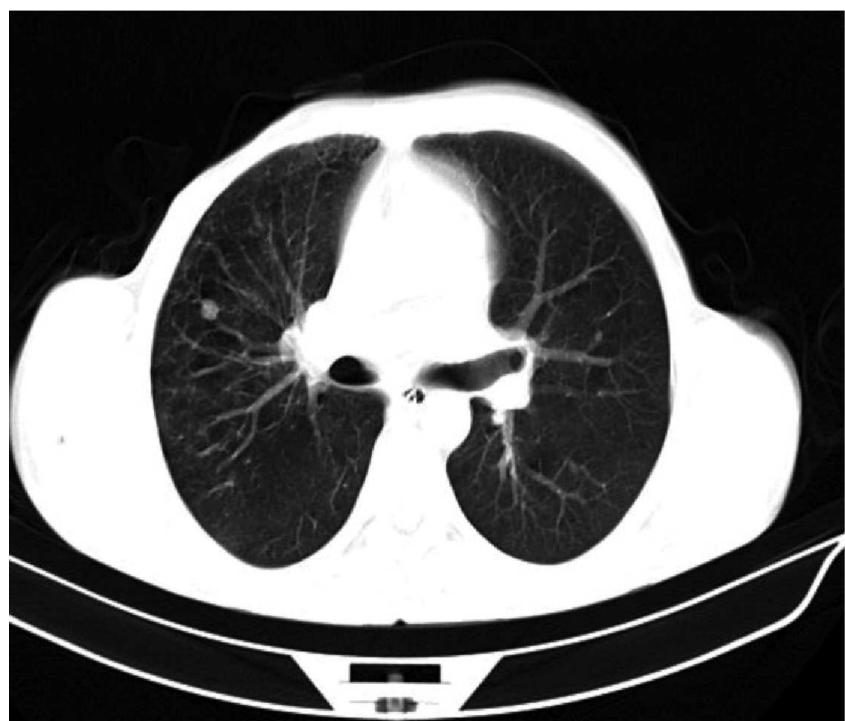

Figure 2 - Computed tomography of the chest showing right lung metastasis. 
ses $^{11}$. In agreement with these authors, we do not believe that the use of chest $\mathrm{CT}$ for all patients with head and neck cancer will significantly encumber any health system; however, the selection of patients at higher risk of alterations, according to the parameters mentioned above, can lead to a more rational use of this method.

The PET/CT has been highlighted as effective in detecting chest metastases or synchronous primary lung tumors, but at the moment, it still has a higher cost than $C T$, is not as widespread, and some studies do not show diagnostic superiority both in early cases and in newly diagnosed ones as for the possible doubts, like the uncharacteristic micronodules ${ }^{8,11}$. The dramatic change in technology in recent years also enhances the use of CT, the advent of multi-slice CT in the 1990s enabling shorter examination time, closer proximity in cuts and higher detailing of dimensions and objects' characteristics ${ }^{7}$.

Surgical treatment or rescue radiation therapy are the leading solution in managing patients with recurrent head and neck tumors. Distant metastasis must be properly identified for due treatment planning. In a meta-analysis of ten articles with 797 PET-CT scans of 756 patients, the sensitivity and specificity of the method were, respectively, $92 \%$ and $95 \%^{12}$. CT is the single most important technique for the detection of distant metastases and second primary tumors, though with sensitivity ranging from $40 \%$ to $74 \%{ }^{13,14}$. However, when comparing the two methods in 37 patients, sensitivity, specificity and predictive values for positive and negative tests were, respectively, 100\%, 94\%, $86 \%$ and $100 \%$ for $\mathrm{CT}$, and $92 \%, 87 \%, 74 \% 97 \%$ for PET-CT. The methods were strictly consistent in 32/37 (86\%) cases $^{15}$.

In our study, the high frequency of altered examinations (66.6\%) reinforce its use and causes it to be incorporated as a complement in the diagnosis / staging of head and neck cancer cases in our department. These patients are often active smokers, which emphasizes the theory of field cancerization ${ }^{9}$, justifying a broader investigation, in addition to explaining the most frequently found change, pulmonary emphysema or alterations suggestive of COPD, which also have the cigarette as predominant etiologic agent.

The second most common finding was the presence of uncharacteristic micronodules. In the evaluation of pulmonary nodules, guidelines published by the Fleishner Society ${ }^{16}$ recommend that nodules measuring $4 \mathrm{~mm}$ or less in patients at high risk of developing malignancy should be followed by $\mathrm{CT}$ in 12 months, without repetition if remaining unchanged; nodules measuring 4-6mm must be followed by $C T$ in $6-12$ months intervals, and then at 18-24 months if unchanged; the ones measuring 6-8mm nodes must have a follow-up with CT every 3-6 months and then at 9-12 months when unchanged; and those measuring up to $8 \mathrm{~mm}$ should be pursued with CT at months 3, 9 and 24 months, with dynamic contrast, and PET / CT or biopsy should be considered, the latter being a $\mathrm{n}$ exception conduct, as it has low accuracy and is associated with pneumothorax.

The presence of thoracic metastases occurred in $12.9 \%$ of exams, a figure considered very important and crucial to the consolidation of the use of $\mathrm{CT}$ in the diagnostic workup of head and neck cancer, since their presence can dramatically change the initial therapy proposal. This prevalence is in line with other published data, which found the presence of metastases in $10.8 \%$ and $19 \%^{7}$. Also in relation to thoracic metastases, the majority affected the lung, but they also occurred in the mediastinum and spinal cord, all with good accuracy detection by CT. The mediastinal location also deserves special attention because, as seen in autopsies ${ }^{17}$, approximately $23 \%$ to $34 \%$ of patients with distant metastases had metastatic lymph nodes in that area, justifying a more accurate screening on these occasions.

Thoracic enlarged lymph nodes was the fourth most frequent finding and may, as in other regions of the body, be inflammatory, infectious or neoplastic in origin and can also mask neoplastic alterations. These enlarged lymph nodes were identified predominantly in the mediastinum, but also occurred in the perihilar region and in the armpit in one case of a patient with head and neck tumor and past breast cancer history, being referred to puncture biopsy.

Active tuberculosis or its sequelae was also an important finding, with $6.6 \%$, consistent with the high prevalence of this disease in our country and the common characteristic of low socioeconomic status between it and head and neck cancer. In some cases it increased morbidity, and in others it caused the association the triple therapy with the initial treatment proposal. Lung inflammatory and infectious signs were common (6.6\%), due to aspiration component peculiar to tumors in some regions of the head and neck, such as the larynx, besides the direct irritant and deleterious effect of smoking on lung parenchyma. Lastly, among the most important findings described herein, there is pleural thickening or effusions (6.6\%), in some cases associated with the previously cited lung diseases or due to neoplasms arising in the lung, besides lung and spinal metastases. In such cases, we used puncture biopsy and cytologic evaluation for clarification, with a frequent need for a new puncture when the test was positive for malignancy.

Although there are still no well-stratified guidelines on the need for CT, particularly in the early cases, we routinely use this examination in all newly admitted cases and post-treatment follow-ups.

In conclusion, the prevalence of CT exams with alterations and the considerable rate of detected metastases indicate that chest CT should be required for diagnosis and / or staging in cases of head and neck cancer. 


\section{R E S U M O}

Objetivo: avaliar a prevalência de alterações encontradas na tomografia computadorizada (TC) de tórax em pacientes com carcinoma epidermóide de cabeça e pescoço. Métodos: Foram analisadas retrospectivamente 209 TC de tórax de pacientes com carcinoma epidermoide de cabeça e pescoço. As alterações tomográficas foram estratificadas como: inflamatórias/infecciosas, parenquimatosas, nodulares incaracterísticas e nodulares metastáticas/tumorais Resultados: foram diagnosticadas alterações em 66,6 \% dos exames. Destes, 25,3\% representaram enfisema pulmonar; 18,8\% micronódulos incaracterísticos; 12,9\% metástases; $11,9 \%$ de linfonodomegalias torácicas; e, em 6,6\%, foram detectadas tuberculose pulmonar ativa ou sequela, pneumonia ou sinais inflamatórios/infecciosos e espessamento ou derrame pleural. Conclusão: a prevalência de exames com alteração e o considerável índice de metástases detectadas, indicam que a TC de tórax deve ser solicitada para complementação diagnóstica e/ou estadiamento nos casos de câncer de cabeça e pescoço.

Descritores: Carcinoma de Células Escamosas. Neoplasias de Cabeça e Pescoço. Tomografia Computadorizada por Raios X. Estadiamento de Neoplasias. Programas de Rastreamento.

\section{REFERENCES}

1. Reiner B, Siegel E, Sawyer R, Brocato RM, Maroney M, Hooper F. The impact of routine CT of the chest on the diagnosis and management of newly diagnosed squamous cell carcinoma of the head and neck. AJR Am J Roentgenol. 1997;169(3):667-71.

2. Ong TK, Kerawala CJ, Martin IC, Stafford FW. The role of thorax imaging in staging head and neck squamous cell carcinoma. J Craniomaxillofac Surg. 1999;27(6):339-44.

3. Houghton DJ, Hughes ML, Garvey C, Beasley NJ, Hamilton JW, Gerlinger I, et al. Role of chest CT scanning in the management of patients presenting with head and neck cancer. Head Neck. 1998;20(7):614-8.

4. Dinkel E, Mundinger A, Schopp D, Grosser G, Hauenstein KH. Diagnostic imaging in metastatic lung disease. Lung. 1990;168 Suppl:1129-36

5. American Joint Committee on Cancer. In: Greene FL, Page DL, Fleming ID, Fritz A, Balch CM, Haller DG, et al. Manual for staging of cancer. $6^{\text {th }}$ ed. Philadelphia: Lippincott; 2002.

6. Quint LE, Glazer GM, Gross BH. Primary and metastatic malignancy, In: Putman CE, editors. Diagnostic imaging of the lung. New York: Marcel Dekker; 1990. p.199-251.

7. Beech TJ, Coulson C, Najran P, Olliff J, Jennings C. How good is a chest $\mathrm{CT}$ scan at predicting the risk of pulmonary metastatic disease in patients with head and neck cancer? A retrospective observational study. Clin Otolaryngol. 2010:35(6):474-8.

8. McLeod NM, Jess A, Anand R, Tilley E, Higgins B, Brennan PA. Role of chest $C T$ in staging of oropharyngeal cancer: a systematic review. Head Neck. 2009;31(4):548-55

9. Glynn F, Brennan S, O'Leary G. CT staging and surveillance of the thorax in patients with newly diagnosed and recurrent squamous cell carcinoma of the head and neck: is it necessary? Eur Arch Otorhinolaryngol. 2006:263(10):943-5.

10. Hsu YB, Chu PY, Liu JC, Lan MC, Chang SY, Tsai TL, et al. Role of chest computed tomography in head and neck cancer. Arch Otolaryngol Head Neck Surg. 2008;134(10):1050-4.
11. Loh KS, Brown DH, Baker JT, Gilbert RW, Gullane PJ, Irish JC. A rational approach to pulmonary screening in newly diagnosed head and neck cancer. Head Neck. 2005;27(11):990-4.

12. Gao S, Li S, Yang X, Tang Q. 18FDG PET-CT for distant metastases in patients with recurrent head and neck cancer after definitive treatment. A meta-analysis. Oral Oncol. 2014;50(3):163-7.

13. Ng SH, Chan SC, Liao CT, Chang JT, Ko SF, Wang HM, et al. Distant metastases and synchronous second primary tumors in patients with newly diagnosed oropharyngeal and hypopharyngeal carcinomas: evaluation of (18)F-FDG PET and extended-field multidetector row CT. Neuroradiology. 2008:50(11):969-79.

14. Krabbe CA, Pruim J, van der Laan BF, Rödiger LA, Roodenburg JL. FDG-PET and detection of distant metastases and simultaneous tumors in head and neck squamous cell carcinoma: a comparison with chest radiography and chest CT. Oral Oncol. 2009;45(3):23440

15. Fakhry N, Michel J, Colavolpe C, Varoquaux A, Dessi P, Giovanni A. Screening for distant metastases before salvage surgery in patients with recurrent head and neck squamous cell carcinoma: a retrospective case series comparing thoraco-abdominal $\mathrm{CT}$, positron emission tomography and abdominal ultrasound. Clin Otolaryngol. 2012:37(3):197-206

16. MacMahon H, Austin JH, Gamsu G, Herold CJ, Jett JR, Naidich DP, et al. Guidelines for management of small pulmonary nodules detected on CT scans: a statement from the Fleischner Society. Radiology. 2005;237(2):395-400

17. de Bree R, Deurloo EE, Snow GB, Leemans CR. Screening for distant metastases in patients with head and neck cancer Laryngoscope. 2000;110(3 Pt 1):397-401.

Received at: 02/04/2015

Accepted for publication: 02/06/2015

Conflict of interest: none.

Source of funding: none.

\section{Mailing address:}

Rogério Aparecido Dedivitis

E-mail: dedivitis.hns@uol.com.br 